\title{
Biodiversity and resilience of arthropod communities after fire disturbance in temperate forests
}

\author{
Marco Moretti · Peter Duelli $\cdot$ Martin K. Obrist
}

Received: 17 November 2005/ Accepted: 26 April 2006/ Published online: 28 June 2006

(C) Springer-Verlag 2006

\begin{abstract}
Changes in ecosystem functions following disturbances are of central concern in ecology and a challenge for ecologists is to understand the factors that affect the resilience of community structures and ecosystem functions. In many forest ecosystems, one such important natural disturbance is fire. The aim of this study was to understand the variation of resilience in six functional groups of invertebrates in response to different fire frequencies in southern Switzerland. We measured resilience by analysing arthropod species composition, abundance and diversity in plots where the elapsed time after single or repeated fires, as determined by dendrochronology, varied. We compared data from these plots with data from plots that had not burned recently and defined high resilience as the rapid recovery of the species composition to that prior to fire. Pooling all functional groups showed that
\end{abstract}

Communicated by Ingolf Steffan-Dewenter

Electronic Supplementary Material Supplementary material is available to authorised users in the online version of this article at http://dx.doi.org/10.1007/s00442-006-0450-z.

M. Moretti

WSL Swiss Federal Research Institute,

Sottostazione Sud delle Alpi,

6501 Bellinzona, Switzerland

P. Duelli · M. K. Obrist

WSL Swiss Federal Research Institute,

8903 Birmensdorf/ZH, Switzerland

M. Moretti ( $\square)$

WSL, Sottostazione Sud delle Alpi, Via Belsoggiorno 22,

6501 Bellinzona, Switzerland

e-mail: marco.moretti@wsl.ch they were more resilient to single fires than to repeated events, recovering 6-14 years after a single fire, but only 17-24 years after the last of several fires. Flying zoophagous and phytophagous arthropods were the most resilient groups. Pollinophagous and epigaeic zoophagous species showed intermediate resilience, while ground-litter saprophagous and saproxylophagous arthropods clearly displayed the lowest resilience to fire. Their species composition 1724 years post-burn still differed markedly from that of the unburned control plots. Depending on the fire history of a forest plot, we found significant differences in the dominance hierarchy among invertebrate species. Any attempt to imitate natural disturbances, such as fire, through forest management must take into account the recovery times of biodiversity, including functional group composition, to ensure the conservation of multiple taxa and ecosystem functions in a sustainable manner.

Keywords Fire regime - Succession - Invertebrates · Functional groups $\cdot$ Switzerland

\section{Introduction}

Forest ecosystems are affected by different kinds of disturbance, including wildfire. Fires often lead to changes in environmental conditions, biomass, species diversity, and ecosystem function (see Peterson et al. 1998; Bengtsson et al. 2000 for reviews). Ecological theory predicts that repeatedly and moderately disturbed ecosystems are likely to have the greatest species richness and to be highly resilient to disturbance (Connell 1978; Walker 1995; Bengtsson 1998). Local 
changes in environmental conditions after disturbance tend to switch the competitive balance between species, allowing a redistribution of dominance among species (Begon et al. 1999).

There is growing recognition that classifying species based on their functional types, rather than their higher taxonomic identity, is a promising approach for tackling ecological questions relating to ecosystem stability, on the scale of ecosystems, landscapes or biomes (e.g. Koricheva et al. 2000). Moreover, focusing on functional groups allows comparisons of distinct biogeographical areas even if the species assemblages are different.

Few studies have explored the effects of disturbance on functional groups of invertebrates, and even fewer have considered many different taxonomic groups concurrently. Findings to date indicate differential responses of various taxa to fire: litter- and soil-dwelling zoophagous and saprophagous species show a high resilience to fire (Wikars 2001; Hanula and Wade 2003; Parr et al. 2004), whereas pollinators are negatively affected in the phrygana ecosystem of Greece (Ne'eman et al. 2000; Potts et al. 2003). On the other hand, saproxylic insects (Similä et al. 2002; Hyvarinen et al. 2005) generally seem to profit from fires, particularly in boreal forests, similar to all highly mobile groups that recolonize quickly (e.g. Holliday 1991; Moretti et al. 2002).

In our approach using space-for-time substitution, resilience to fire was defined as the time needed for the species composition in a site to return to its original state after a disturbance (Begon et al. 1999). Resistance to fire, on the other hand, was measured as the degree of similarity in species composition immediately after a fire ( $<1$ year).

Resistance and resilience to fire are closely related to the fire history of the ecosystem and to the taxa referred to (Bengtsson 2002). In fire-prone regions, resistance and resilience are generally positively correlated with fire frequency (e.g. Parr et al. 2004), while ecosystems free of fire or affected by an increase in fire frequency are highly sensitive to fire (e.g. Rowell and Moore 1999).

In this paper we investigate the resilience of different functional groups of arthropods to fire, analysing community similarity, the number of species and individuals, and changes in the dominance of species within communities at different time intervals following single or repeated fires.

We expect resilience to be highest in mobile groups, and single fires to allow for a faster recovery of functional groups and dominance distributions than repeated fires.

\section{Materials and methods}

\subsection{Study area}

The study area is located on the southern slope of the Swiss Alps in the hilly and mountainous belt dominated by coppice stands of sweet chestnut (Castanea sativa Miller). The study area has a moist, warm temperate climate, which differs from the more southern regions with a Mediterranean climate. Rainfall in summer is about twice as high as in winter (JuneSeptember, about $800 \mathrm{~mm}$; November-February, about $400 \mathrm{~mm}$ ). The area is prone to anthropogenic, fast-spreading surface fires of low or medium intensity during the period of vegetation dormancy (DecemberApril; Moretti et al. 2002).

In our study area fire regimes changed substantially with the introduction of agriculture ca. 7,500 years ago. Reconstruction of fire history by means of charcoal deposited into sediment archives of different sites (Tinner et al. 1999) revealed that anthropogenic fires became much more abundant during the Neolithic (7,500-4,200 years ago) and reached highest frequencies during the Iron Age (2,800-2,000 years ago), when fires were about 3-5 times more frequent than during the past 70 years (Tinner et al. 1998). Pollen and charcoal studies suggest that these anthropogenically increased fire frequencies lead to the transformation of entire vegetation communities in the southern Alps (e.g. Tinner et al. 2005), thus profoundly altering important ecosystem properties. Only with the introduction of chestnut ( $C$. sativa) cultivation by the Romans 2,000 years ago, was slash and burn agriculture abandoned and fire frequencies returned to lower levels. However, these intermediate levels, which are still characteristic for today, are still well above the natural fire frequencies known from prehistoric soil profiles (Tinner et al. 2005).

The study sites were chosen on a south-facing slope (450-850 $\mathrm{m}$ a.s.l.), extending over $15 \mathrm{~km}$ near Locarno $\left(08^{\circ} 44^{\prime} \mathrm{E}, 46^{\circ} 09^{\prime} \mathrm{N}\right)$. The sampling design was based on a space-for-time substitution (Pickett 1989). For this purpose the slope was divided into six sectors of approximately $1 \mathrm{~km}^{2}$, in which a total of 22 study sites (three to four per sector) were selected. The sites were grouped into three categories of fire frequency: the first, the control plots, were defined as unburnt sites, where no fire had occurred for at least 30 years. The records of older fires are less reliable with regard to fire intensity and impacted area. In single-fire sites a fire had occurred only once in the previous 30 years, while in sites of repeated fires, fires have occurred at least 3 times in the previous 30 years. Because each sector had 
a different fire history, it was not possible to have consistent replicate sites with the same fire regime in each sector. However, at least one unburnt (control) site was defined in each sector.

The sites were similar to each other in aspect, slope, soil and plant species composition, but differed in terms of fire frequency and time elapsed since the last fire. The fire history of each site was assessed using dendrochronological methods (Moretti et al. 2002). Based on dendrochronology, the sites were also attributed to four successional stages $(<1,1-3,6-14$, 17-24 years since the last fire; Table 1$)$. The successional stages differed in tree and grass cover, as well as in forest structure (Moretti et al. 2002). Forest canopies were more open and the grass more luxuriant at burnt sites (especially at recently burnt sites) than at unburnt sites. Because of the stump resprouting and the high shoot mortality following fire, sites which had burned repeatedly were more dense than unburned sites and those which had burned only once. The dominant trees at repeatedly burned sites had a smaller diameter at $1.5 \mathrm{~m}$ height than those at unburned sites and those at sites burned only once (Moretti and Barbalat 2004).

\subsection{Invertebrates}

Invertebrates were collected using three different standard methods: pitfall traps, surface eclectors (emergence traps), and combination traps, (Duelli et al. 1999). Together, these methods allowed sampling of ground-dwelling arthropods, as well as flying and flower-visiting species. The pitfall traps consisted of plastic funnels recessed into the soil (with openings $15 \mathrm{~cm}$ in diameter) and mounted on top of a plastic bottle containing $2 \%$ formaldehyde solution. A roof $10 \mathrm{~cm}$ above the traps provided protection from rain.

Surface eclectors (Brunhes 1981) consisted of a pyramid-like construction $(50 \times 50 \mathrm{~cm}$ at the base $)$ fixed on the ground and covered with a fine black wire-mesh (mesh width $<0.5 \mathrm{~mm}$ ) in order to preserve the microclimatic conditions. Emerging insects were trapped in collection vials on top of the dark pyramid, where they tried to escape to the light. Combination traps, consisting of a non-directional window (interception) trap combined with a yellow pan, filled with water and detergent to reduce its surface tension, were placed at a height of $1.5 \mathrm{~m}$ above the ground. Detailed descriptions of the trapping characteristics of the traps used are available in Obrist and Duelli (1996), Duelli et al. (1999), Martikainen et al. (2000) and Moretti et al. (2002).

At each of the 22 sites, we installed three trap triplets (a pitfall trap, a combination trap, and an eclector), resulting in a total of 66 traps of each type (Table 1). The minimum distance between traps of the same type at each site was $10 \mathrm{~m}$, while the average distance between the sites was $301 \pm 128 \mathrm{~m}$. The traps were emptied weekly from March to September 1997. Collecting took place during 28 sampling periods, covering the main activity season of most taxa.

Totally, 111 families from seven taxonomic orders of invertebrates [Isopoda (two), Aranea (22), Coleoptera (59), Hemiptera (14), Neuroptera (four), Hymenoptera (nine), Diptera (one)] were identified to species level. These orders comprise the main terrestrial invertebrate groups for which there is good systematic and ecological knowledge available in Switzerland. Each species was assigned to one (or two, if larvae and adults belong to different groups) of six functional groups, determined by taxonomic experts. These were ground-litter saprophagous species (decomposers on the ground and litter layer), flying zoophagous, epigaeic zoophagous (surface-dwelling predators), phytophagous (sucking and leaf-eating species), pollinophagous (pollinators and flower-visiting insects), and saproxylophagous arthropods (wood-eating species).

\subsection{Data analysis}

First of all we analysed the spatial auto-correlations among the sites for each functional group by applying a multivariate Mantel correlogram based on the normalized Mantel statistic $\left(r_{\mathrm{M}}\right)$. Significance was assessed by using Monte Carlo randomization (999 permutations)

Table 1 Trap sites grouped into the three categories of fire frequency. Unburnt Sites which had not burnt in the last 30 years, Single fire sites with one fire in the last 30 years, Repeated fires sites with three to four fires in the last 30 years

\begin{tabular}{|c|c|c|c|c|c|c|}
\hline \multirow[t]{2}{*}{ Fire frequency } & \multirow[t]{2}{*}{ Unburnt } & \multicolumn{4}{|c|}{ Time since last fire } & \multirow[t]{2}{*}{ Total } \\
\hline & & $<1$ Year & 1-3 Years & 6-14 Years & 17-24 Years & \\
\hline Unburnt (control) & 18 & & & & & 18 \\
\hline Single fire & & 3 & 6 & 6 & 9 & 24 \\
\hline Repeated fires & & 3 & 6 & 12 & 3 & 24 \\
\hline Total trap triplet locations & 18 & 6 & 12 & 18 & 12 & 66 \\
\hline
\end{tabular}


and Bonferroni correction. The method is designed, in particular, to describe the spatial structure of species assemblages (Legendre and Legendre 1998).

For each functional group and for all groups pooled, we then calculated the number of species and individuals caught at each of the 66 trap locations. Mean values $( \pm \mathrm{SD})$ were calculated per successional stage following single and repeated fires, and for the plots without fire. The mean values of normally distributed data sets (Lilliefors test, Systat 10.0; SPSS, Chicago, Ill.) were analysed by ANOVA and a subsequent Scheffé post hoc test using Systat (SPSS). When the homogeneity of variances was not achieved, the data were $\log (x+1)$-transformed. Non-parametric KruskalWallis ANOVA by rank and the by Mann-Whitney $U$ test with Bonferroni correction between two groups were applied if normality was not achieved (Zar 1984).

For all pairs of trap locations we calculated van der Maarel similarity coefficients for abundance data (Wildi and Orloci 1996) and statistically compared community similarity with ANOVA.

The Van der Maarel similarity coefficient is given by:

$S_{j k}=\frac{\sum_{i} x_{i j} x_{i k}}{\sum_{i}\left(x_{i j}-x_{i k}\right)^{2}+\sum_{i} x_{i j} x_{i k}}$

where $x_{i j}=$ number of individuals of species $i$ in site $j$; $i=$ species; $j, k=$ sites. $S_{j k}=1$ if $x_{i j}=x_{i k}$ for every species $i ; S_{j k}=0$ if sites $j$ and $k$ do not share any species.

For this analysis, we only considered those species for which the total number of all individuals sampled was at least five. The number of individuals was $\log (x+1)$ transformed in order to reduce the weight of very abundant species. Because all data were normally distributed, we used ANOVA with a subsequent Scheffé post hoc test to compare the mean values $( \pm \mathrm{SD})$ of the similarity indices between the communities at each successional stage with those of the unburnt sites (control).

Numerical dominance (relative abundance) was divided into four categories $(<1 \%, 1.0-3.1 \%, 3.2-9.9 \%$, $\geq 10 \%$ ) (Mühlenberg 1993) and is referred to as "dominance" throughout the text. We analysed the changes in species dominance distribution in burned and unburned sites by comparing the median values of the relative abundance of dominant $(\geq 10 \%)$ and subdominant (3.2-9.9\%) species for each post-burn stage.

Finally, the degree to which species changed dominance was analysed by selecting species sampled with more than ten individuals per study site in any of the following categories: unburnt sites, freshly burnt sites ( $<1$ year after the fire; first successional stage) and sites burnt 17-24 years ago (last successional stage). Any species that varied at least tenfold before and after the fire was tested for significance of dominance change by ANOVA, or by the equivalent KruskalWallace rank ANOVA if normality was not achieved. Lacking standards, we arbitrarily chose a tenfold change (1 order of magnitude) as critical since it seems severe enough for most invertebrate groups.

\section{Results}

A total of 1,085 species were identified from a total of 110,482 individuals; 284 species $(26 \%)$ were observed exclusively at one sample site, while at least five individuals were sampled of each of 486 species $(53 \%)$. The latter were attributed to one or more functional groups: $42(8.6 \%)$ were assigned to ground-litter saprophagous species, $146(30.0 \%)$ to epigaeic zoophages, 166 (34.2\%) to flying zoophages, 66 (13.6\%) to phytophages, $262(53.9 \%)$ to pollinophages, and 136 $(28.0 \%)$ to saproxylophages (Table 2). As a species may be attributed to more than one functional group (see Materials and methods), the sum of the percentages of the different groups is higher than $100 \%$.

All analyses were conducted treating the 22 sites as independent replicates (Hurlbert 1984), after checking for non-significant spatial autocorrelation of each functional group (multivariate Mantel correlogram).

Table 2 Total number of species and individuals (in parentheses) of six functional groups from the seven selected orders (Isopoda, Aranea, Coleoptera, Heteroptera, Neuroptera, Hymenoptera, Diptera)

\begin{tabular}{|c|c|c|c|c|c|c|c|c|c|}
\hline Functional groups & Isopoda & Aranea & Coloptera & Heteroptera & Neuroptera & $\begin{array}{l}\text { Hymenoptera, } \\
\text { Aculeata }\end{array}$ & $\begin{array}{l}\text { Diptera, } \\
\text { Syrphidae }\end{array}$ & $\begin{array}{l}\text { Total } \\
\text { species }\end{array}$ & $\begin{array}{l}\text { Total } \\
\text { individuals }\end{array}$ \\
\hline $\begin{array}{l}\text { Ground-litter } \\
\text { saprophages }\end{array}$ & $12(1,147)$ & & $17(458)$ & & & $13(9,118)$ & & 42 & 10,723 \\
\hline Epigaeic zoophages & & $70(7,956)$ & $45\left(15^{\prime} 611\right)$ & & & $31(19,650)$ & & 146 & 43,217 \\
\hline Flying zoophages & & & $12(232)$ & $24(1,222)$ & $23(2,578)$ & $80(4,075)$ & $27(2,110)$ & 166 & 10,217 \\
\hline Phytophages & & & $33(9,214)$ & $27(1,454)$ & & $3(175)$ & $3(101)$ & 66 & 10,793 \\
\hline Pollinophages & & & $54(9,063)$ & & & $171(52,375)$ & $37(2,704)$ & 262 & 64,142 \\
\hline Saproxylophages & & & $126(14,383)$ & $4(53)$ & & $1(95)$ & $5(437)$ & 136 & 14,968 \\
\hline
\end{tabular}


The herbivores, flying and epigaeic predators were very marginally affected by spatial autocorrelation (i.e. only one out of 24 distance classes), probably due to the spatial arrangement of burns in the study area and thus to the location of the sample sites.

\subsection{Effect of fire frequency on species richness and abundance}

Fires tended to affect the various taxa and functional groups rather differently. Some showed no observable effects, whereas others had not returned to their initial state even 17-24 years after the fire.

Single fires did not affect the overall number of species or individuals during the four successional stages following burning (Fig. 1a, left). A similar pattern was observed for phytophagous species (Fig. 1c, left). The species richness increased $<1$ year and $1-$ 3 years after fire in flying zoophagous (Fig. 1b, left; ANOVA, $\left.F_{4,42}=5.81, P<0.001\right)$ and in pollinophagous species (Fig. 1d, left; ANOVA, $F_{4,42}=5.92, P<0.001$ ). The number of individuals of the epigaeic zoophagous species, on the other hand, decreased immediately after the fire (ANOVA, $F_{4,42}=4.45, P=0.004$ ), while numbers of ground-litter saprophagous species were still less than in sites 17-24 years following burning (ANOVA, $F_{4,42}=10.29, P<0.001$ ) (Fig. 1e, f, left).

Repeated fires affected the overall number of species (ANOVA, $F_{4,42}=5.01, P=0.003$ ) and the number of individuals significantly $\left(F_{4,42}=4.20, P=0.007\right)$. While the number of species increased gradually until the second successional stage (1-3 years after the last fire) and decreased slightly during the next two stages (6-14 and 17-24 years), a higher number of individuals was observed only 1-3 years after the last fire. A similar pattern was found for the flying zoophagous species (Fig. $1 \mathrm{~b} ; F_{4,42}=6.72, P<0.001$ ) and for pollinophagous species (Fig. $1 \mathrm{~d}$; ANOVA, $F_{4,42}=6.09, P<0.001$ ). While the species richness of the ground-litter saprophages did not change after repeated fires (Fig. 1f, left), the number of species of the epigaeic zoophages increased significantly 1-3 and 6-14 years after the last fire (Fig. 1e, left) (ANOVA, $F_{4,42}=11.11, P<0.001$ ). The number of individuals of both groups (Fig. 1g, left), on the other hand, decreased dramatically immediately after the fire (ANOVA, $F_{4,42}=7.78, P<0.001$ for the saprophages; $F_{4,42}=7.60, P<0.001$ for the epigaeic zoophages) as did, to a lesser extent, the number of saproxylophagous individuals $\left(F_{4,42}=10.56, P<0.001\right)$. During the following successional stages the abundance of all three groups did not recover, not even by the last successional stage (17-24 years after the last fire).

\subsection{Resilience to fire}

Single and repeated fires significantly (Fig. 1a, right) affected the similarity of the overall species assemblage (ANOVA, $F_{4,42}=245.65, P<0.001$ for single fires and $F_{4,42}=180.75, P<0.001$ for repeated fires). After a single fire the overall species composition changed more strongly (the community was less resistant) than after repeated events, but showed higher resilience to single fires than to repeated ones (Fig. 1a, right). After repeated fires, the sites had overall only recovered partially, even at the last successional stage. In a Scheffé post hoc test this difference was significant, especially during the first two successional stages ( $<1$ and $1-$ 3 years after the fire).

For single fires a similar pattern of similarity was observed for most of the functional groups. The phytophagous and the flying zoophagous arthropods (Fig. 1c, b, right) were the most resistant groups and showed the highest resilience to fire, while the epigaeic zoophages (Fig. 1e, right; ANOVA, $F_{4,42}=33.47$, $P<0.001$ ), the ground-litter saprophages (Fig. 1f, right; ANOVA, $\left.F_{4,42}=242.28, P<0.001\right)$, and the saproxylophages (Fig. 1g, right; ANOVA, $F_{4,42}=219.71$, $P<0.001$ ) were the least resilient groups, recovering only 6-14 years after the first fire.

In the case of repeated fires, long-term major changes in species assemblage were observed for the epigaeic zoophagous (ANOVA, $F_{4,42}=132.54$, $P<0.001$ ), ground-litter saprophagous (ANOVA, $\left.F_{4,42}=242.09, \quad P<0.001\right), \quad$ and saproxylophagous (ANOVA, $F_{4,42}=163.65, P<0.001$ ) species. Resistance and resilience to repeated fires were lowest in these three groups. After repeated fires their communities were different from those at the pre-burn stage, even in the last successional stage after burning.

\subsection{Dominance distribution after the fire}

At unburnt sites the number of dominant $(\geq 10 \%)$ and subdominant (3.2-9.9\%) species varied from a maximum of six epigaeic zoophagous and flying zoophagous species, to a minimum of three saproxylophagous species (Table 3). The functional groups that underwent major changes in dominance after a fire were the epigaeic and flying zoophagous, as well as the saproxylophagous species. More than $60 \%$ of the species with dominance $\geq 3.2 \%$ were replaced by minor species (dominance $<3.2 \%$ ) during the first two successional stages after the fire. For the other groups, only $30 \%$ of the dominant and subdominant species were replaced shortly after fires. In the third successional stage (614 years after the last event), the dominant and sub- 
Fig. 1a-g Mean number of species and individuals $( \pm \mathrm{SE})$, and mean of similarity coefficient $( \pm \mathrm{SD})$ (van der Maarel) for species assemblages at the different successional stages $(<1,1-3$, 6-14, 17-24 years) after single (S; open circle) and repeated ( $\mathrm{R}$; filled circle) fires versus species assemblages at the 18 unburnt sites as controls.

Data points with different letters are significantly different. $* P<0.05$, $* * P<0.01, * * * P<0.001$, n.s. not significant a) Overall functional groups
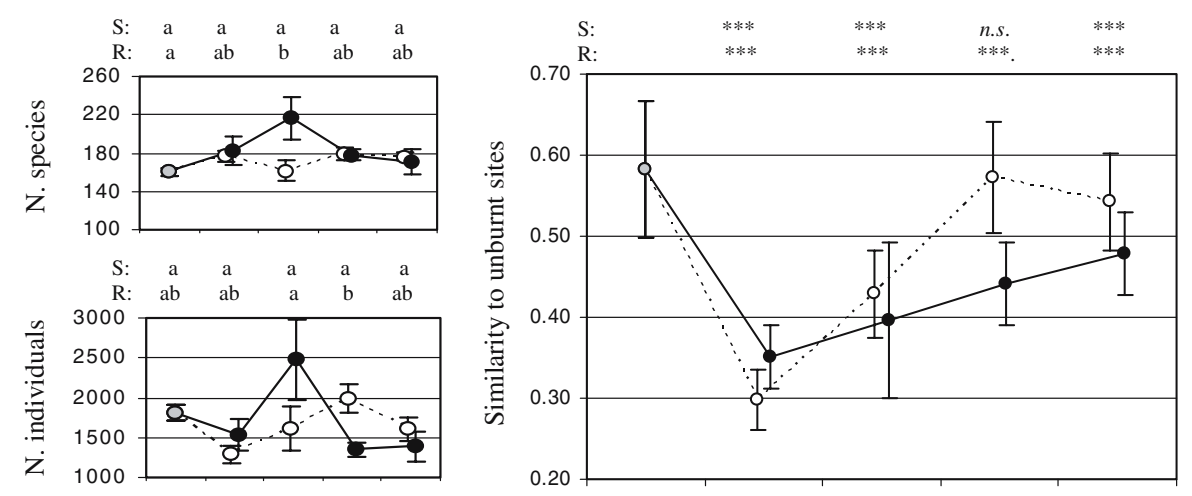

b) Flying zoophages
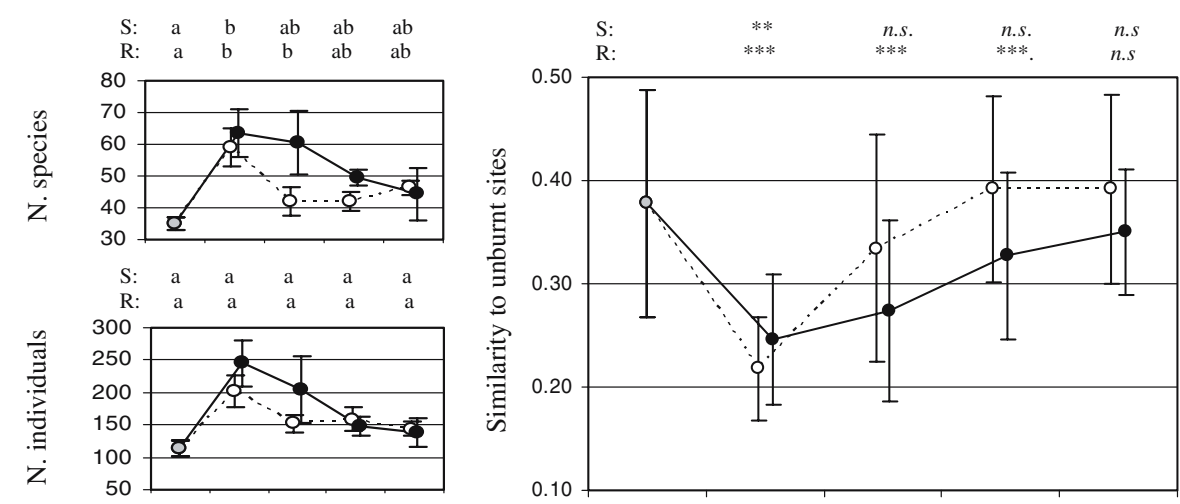

\section{c)Phytophages}
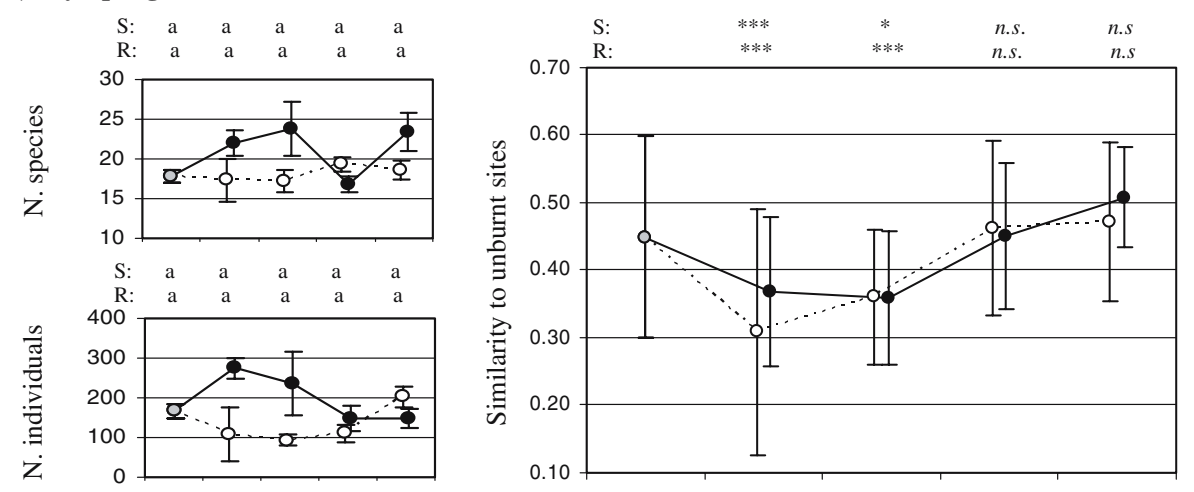

d) Pollinophages

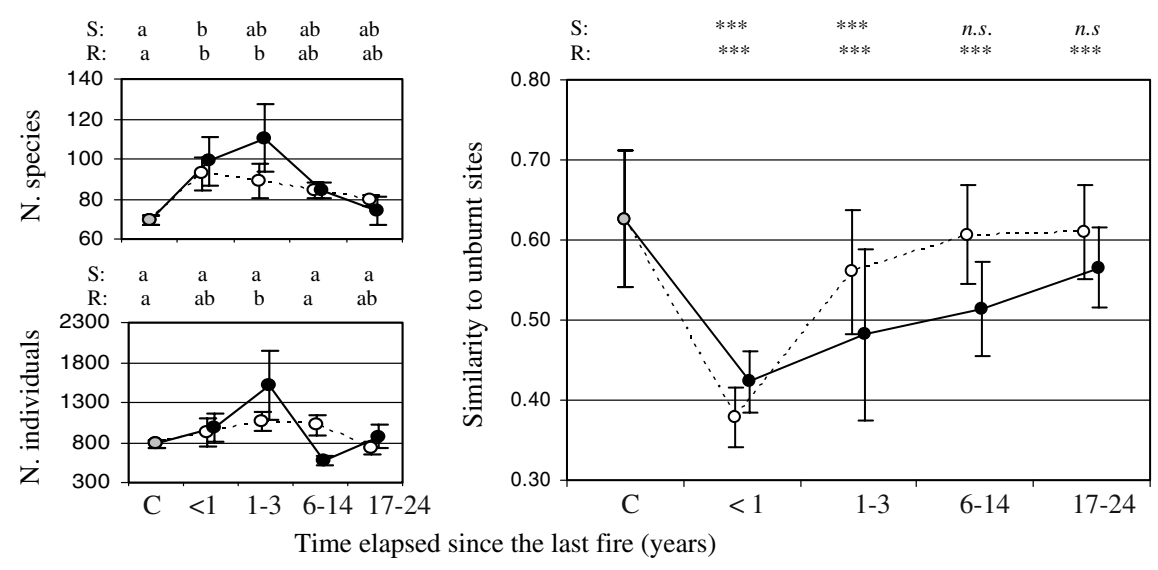


Fig. 1a-g continued

e) Epigaeic zoophages
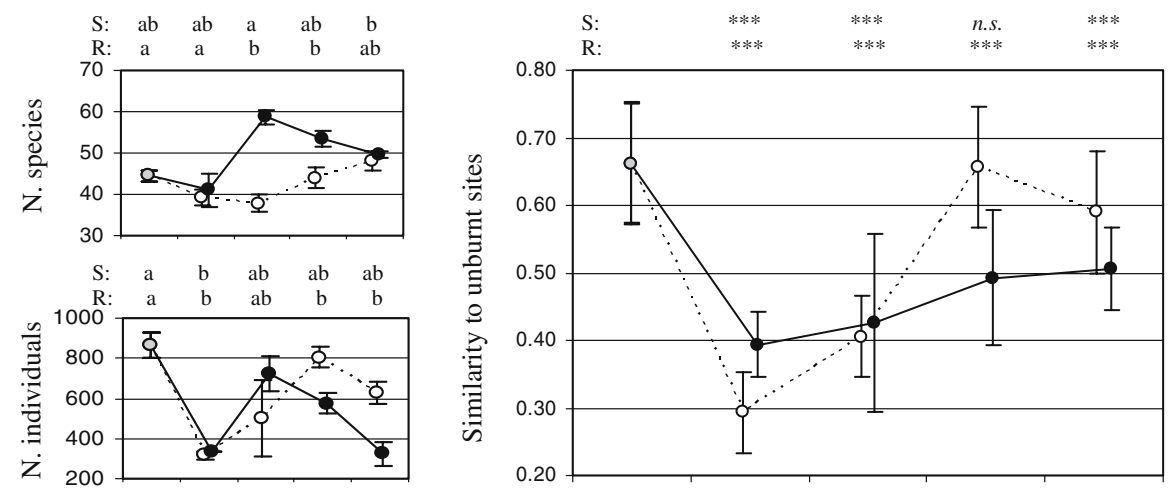

f) Ground-litter saprophages
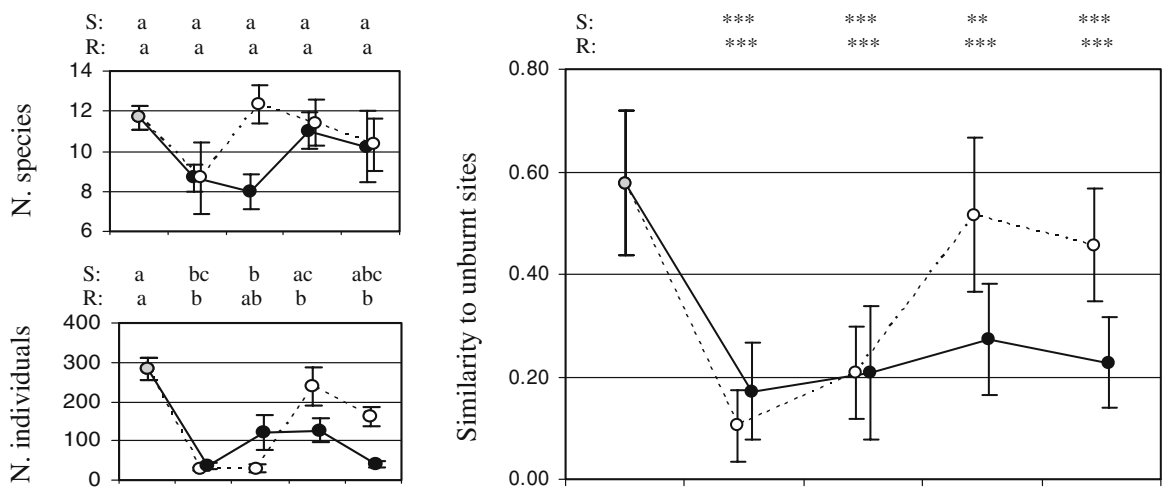

g) Saproxylophages
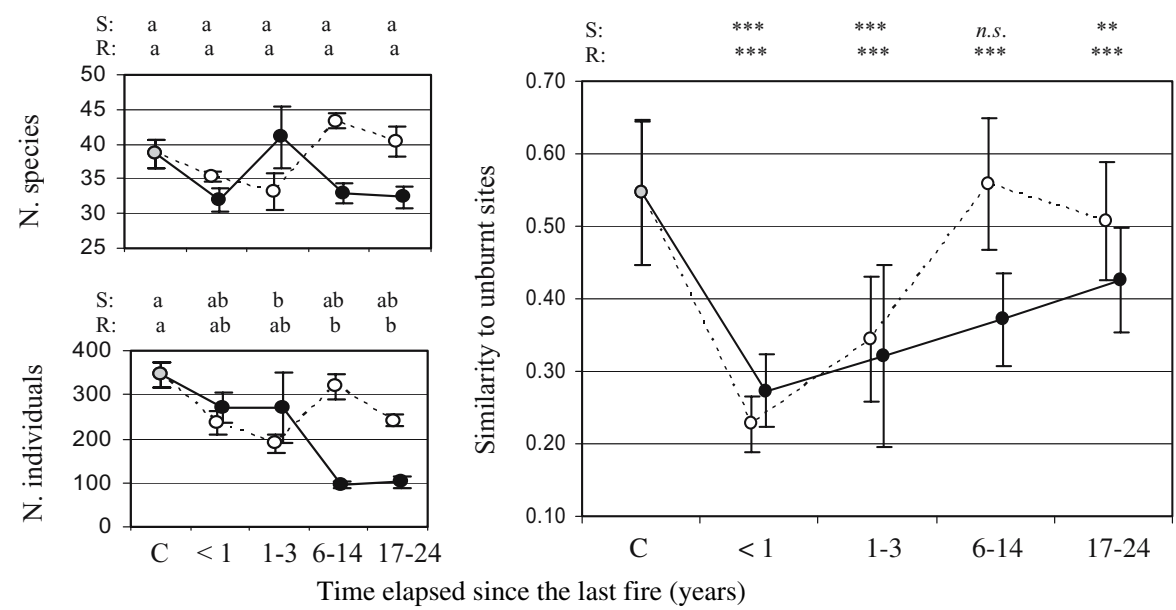

dominant species of most functional groups recovered completely after repeated fires. Exceptions were the flying zoophages and the ground-litter saprophages.

Such processes of dominance redistribution after fire increase the proportion of newly dominant or subdominant species about threefold (from five to 16 species) during the first two successional stages, reaching nearly 4 times as many (from five to 19 species) at the last stage (Fig. 2). On the other hand, the dominant and subdominant species in the unburnt forests decreased by half during the first year following a fire, but they recovered almost completely 6-14 years after the fire.

\subsection{Species most affected by fire}

Among the species sampled with an average of at least ten individuals per study site at unburnt or freshly burnt sites, 24 species increased at least tenfold at freshly burnt sites, but only three of them were sig- 


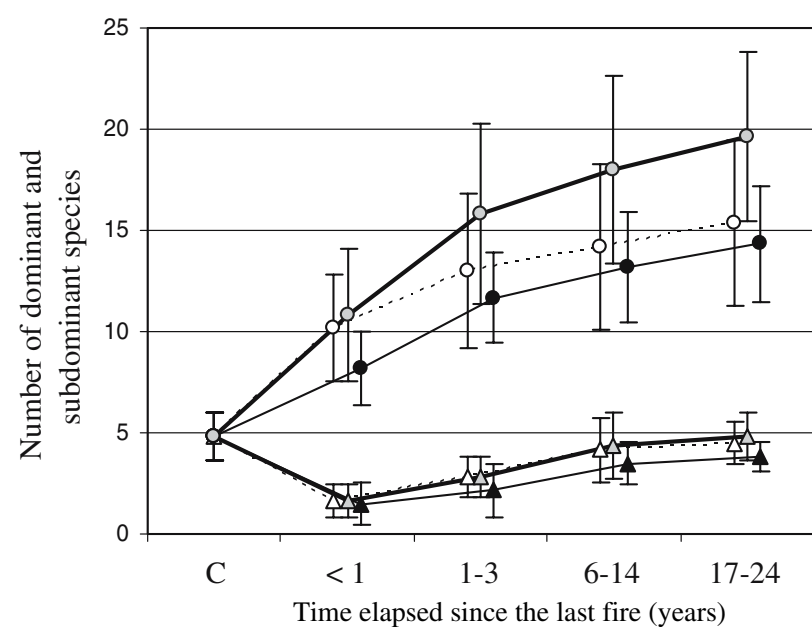

Fig. 2 Changes in the number of dominant and subdominant species after the fire. Cumulative number of new dominant and subdominant species (circles), and those remaining intact (triangles) during the successional stages $(<1,1-3,6-14,17-$ 24 years) after single (black symbols) and repeated (empty symbols) fires. The grey symbols and the thicker line indicate the overall variation of dominant and subdominant species after fire

nificantly more abundant at the last successional stage compared to unburnt sites (Table 4). The most favoured species belonged to the pollinophagous taxa $(+47.4 \%$ after a single fire and $+45.0 \%$ after repeated fires) such as Hylaeus communis, Lasioglossum rufitarse, Lasioglossum pygmaeus (Hymenoptera), Sphaerophoria scripta (Diptera) and Oedemera flavipes (Coleoptera). Similarly some saproxylophagous taxa increased their abundance $(+31.6 \%$ after a single fire and $+35.0 \%$ after repeated fires), e.g. Anthreneus museorum, Corticarina similata, and Orius horvathi (Coleoptera). Three species were still significantly more abundant at the last successional stages: the pollinophagous Hylaeus gibbus, Lasioglossum morio (Hymenoptera), and the saproxylophagous Harpocera thoracica (Hemiptera).

On the other hand, 28 species disappeared or decreased to one-tenth their number shortly after the fire. Fourteen of them remained significantly less abundant at the last successional stage compared to the unburnt sites (Table 4). The most negatively affected species belonged to the epigaeic zoophagous group $(-45.0 \%$ after a single fire and $-50.0 \%$ after repeated fires), e.g. the ants Stenamma striolatum, Aphaenogaster subterranean, Leptothorax parvulus and L. nylanderi (Hymenoptera), Pterostichus micans (Coleoptera), and Lepthyphantes flavipes (Aranea). The abundance of some pollinophagous species decreased in a similar way $(-30.0 \%$ after a single fire and $-21.4 \%$ after repeated fires), as in Lasioglossum politum (Hymenoptera), or in the saproxylophagous
Ptinus bidens (Coleoptera). Fourteen species did not recover at this stage, particularly at repeatedly burnt sites: the epigaeic zoophagous Coelotes mediocris (Aranea), Aphaenogaster subterranea, Leptothorax nylanderi, L. parvulus, Stenamma striatulum (Hymenoptera Formicidae), the pollinophagous Andrena fulvata, A. nigroaenea, Lasioglossum politum (Hymenoptera), the ground-litter saprophagous Dienerella clathrata, Enicmus minutus, Lathridius nodifer (Coleoptera), and the saproxylophagous Ptinus bidens (Coleoptera).

\section{Discussion}

\subsection{Species composition and functional groups}

To assess ecological resilience we can either focus on the taxonomic level and measure the time it takes after an event to return to the original species composition, or we can focus on the functional level, where it is ecologically relevant whether a species accomplishes one or several ecological functions in a lifetime. Here we advocate the latter approach. Accordingly, we assigned every species to one or two of six functional groups, depending on its life history traits as larvae or adults. Out of the 1,085 identified species, 281 were counted twice in the analysis of the functional groups. As the double-counting species were equally distributed among the six functional groups, we judge a potential bias in the analysis of the entity of all functional groups as negligible.

In the analysis of single functional groups this bias was not involved as every species only contributed once to a specific group.

\subsection{Abundance, diversity and resilience to fire}

The response of invertebrates to fire results from both direct mortality and post-fire succession. Direct mortality depends on the fire regime, but also on the biotic conditions during the fire, such as the particular habitat occupied by a species, its developmental stage, and its mobility during the fire (e.g. Niwa and Peck 2002; Hoffmann 2003).

Post-fire succession depends on the new environmental conditions, on the rate at which differences in competitive abilities are expressed in space and time (Huston 1979, 1994), and on the potential for immigration, i.e. on the composition and structure of the surrounding habitats. The species compositions before a fire, particularly the presence of minor species that are able to take advantage of post-burn conditions, are 
important for the development of the community during post-fire succession. The surviving and quickly immigrating species are the ones that have the greatest advantage in early stages of the succession. Our results for all functional groups at burned sites, particularly after repeated fires, corroborate the observation of several other authors that disturbances promote species richness in forests (e.g. Haydon et al. 2000; Similä et al. 2002; Sippola et al. 2002).

The long-term dynamics of space and the heterogeneity of structure and resources result in a variety of more or less temporary habitats for a large number of species (e.g. Reed et al. 2000; Debinski et al. 2001; Mielikainen and Hynynen 2003). This is predicted by the mosaic concept (e.g. Forman and Gordon 1986; Duelli 1997) and the patch-dynamics model (Tilman 1982). Epigaeic predators provide evidence of these dynamics through an increase in species richness and a change in species composition in a diverse environmental microhabitat (Moretti et al. 2002). This was to be expected as we observed a general increase in the number of invertebrates as potential prey after the fires in our study.

The winter fires of the contemporary chestnut forests in the southern Alps tend to be of low or medium intensity (Marxer 2003). In order to link our results with the intermediate disturbance hypothesis (Connell 1978), we have to be able to sample and quantify a broad spectrum of disturbance intensities. Since there are no records of fires of high intensity, the frequency of repeated fires or the time elapsed since the last fire can also be measures of disturbance intensity (Collins et al. 1995; Li et al. 2004). But even then, the fact that our data show a tendency of species richness increasing with fire frequency suggests that these chestnut communities are still in the increasing phase of the hump predicted by the intermediate disturbance hypothesis (Huston 1979).

Post-fire changes in species composition vary according to fire frequency. In several functional groups we found higher resilience to single rather than to repeated fires. The temporary increase in the number of pollinophagous, phytophagous and flying zoophagous individuals and species in burnt areas and their high resilience to fire is very likely due to their high mobility. The increase observed in these flying arthropods arises from their opportunistic exploitation of suitable resources on a large spatial scale in a landscape mosaic created by previous fires, forest clearings, natural gaps, fire residuals, and intact patches of forest (e.g. Moretti et al. 2004). Most ecological processes and interactions depend on spatial scales much larger than a single habitat. Flying invertebrate groups may therefore benefit more from ecological processes related to disturbances on a landscape scale (Steffan-Dewenter et al. 2002).

The pollinophagous species in our study did not show the long-term decline after fire in the Mediterranean due to post-fire floral resource quality as reported by other authors (e.g. Ne'eman et al. 2000; Potts et al. 2003), but rather a complete recovery of the prefire situation 17-24 years after the fire. This can be explained by the quick recovery of the chestnut trees, which are known to be a high-quality nectar source for wild and honey bees (e.g. Crailsheim 1992). This also confirms the findings of Potts et al. (2005) that nesting resource availability for bees varied markedly across habitats in different stages of post-fire regeneration in the Mediterranean, thus influencing the bee community structure and species richness.

The ground-litter saprophagous and saproxylophagous arthropods, on the other hand, showed the lowest resilience to repeated fires of all the groups. The species richness of both was not significantly affected by fire, but the number of individuals decreased dramatically. The main reasons for the long-term changes in species composition observed following repeated disturbances are probably the change in the post-fire ground-habitat conditions (Siemann et al. 1997; Wikars 2001) and in the coarse woody debris diversity (Stephens and Moghaddas 2005), as well as the high specialisation and sensitivity to habitat changes of many saproxylophagous species (Dajoz 2000; Wermelinger et al. 2002).

\subsection{Dominance shifts}

Many authors emphasise that disturbance plays a major role in driving evolutionary adaptations (e.g. Walker et al. 1999; Nyström and Folke 2001; Peterson 2002), but responses to disturbance vary between species. Whereas certain species benefit from a particular type of disturbance, others suffer and decrease, depending on their specific adaptation. According to Huston (1979, 1994), the species diversity found at any location is the result of a dynamic equilibrium between competitive displacement and disturbance. In our case changes in resources could account for the change in species composition, particularly in the case of repeated fires and fires that occurred $<1$ and 13 years before the investigation. Our results suggest that changes and fluctuations in environmental postfire conditions altered the species composition among all functional groups. This resulted in a redistribution of the species dominance among the community groups whereby some formerly inferior competitors 
became dominant. Our results show that the species favoured by disturbance were already present in the community and had survived exogenic and anthropogenous disturbances in the past. They either survived during the fires or immigrated from the surrounding area. This result could explain the high resilience to fire observed in our study by most functional groups. According to the resilience hypothesis (Ludwig et al. 1997), dominant and minor species may respond differently even when they are functionally similar. In the majority of the functional groups in our study, dominant species were primarily affected negatively by disturbances, whereas some minor species $(<3.1 \%$ of dominance) seem to have benefited from new opportunities and increased, thus becoming dominant or subdominant.

\subsection{Responses of the species most affected by fire}

The pollinophagous and, in particular, mobile saproxylophagous species were positively affected by fire. They exploit open habitats and forest edges, such as gaps created by fires or clearings, as well as rocky sites, on a large spatial scale (i.e. Lasioglossum rufitarse, $L$. pygmaeus (Hymenoptera), Sphaerophoria scripta (Diptera), and Oedemera flavipes (Coleoptera)). Some of those species depend on dead wood for a certain period of their development. Examples are Hylaeus gibbus and Lasioglossum morio (Hymenoptera), which nest in the galleries of xylophagous beetles (Westrich 1989), and Xylota segnis (Diptera), which has a xylophagous larval stage (Röder 1990). For these species, as well as for saproxylophagous taxa like Leptura maculata, Stenopterus rufus, Corticarina ferruginea and C. similata (Coleoptera) (Bense 1995), fire is likely to play an important role as it creates new structural elements and habitats such as gaps and dead wood.

The epigaeic zoophagous and, to a lesser extent, the ground-litter saprophagous species suffered most from the fire. Species associated with old-growth forests were particularly affected, e.g. Leptothorax parvulus, L. nylanderi, Aphaenogaster subterranea, Stenamma striatulus (Hymenoptera Formicidae), Pterostichus micans, Dienerella clathrata, Enicumus minutes and Lathridius nodifer (Coleoptera). Many of them are small and sedentary, and therefore potentially vulnerable to fire (Koch 1989; Seifert 1996). Many pollinophagous species, like the wild bees Lasioglossum politum, Andrena haemorrhoa, A. nigroaenea and $A$. fulvata, were also negatively affected by fire. These species are particularly vulnerable to fire because they nest on the ground, in the litter layer, under stones and wood (Seifert 1996).
4.5 Implications for forest management

In the forests of the southern Alps, it seems that most invertebrate species have adapted to past disturbance regimes created by fire and human exploitation. There is good evidence (e.g. Tinner et al. 1999) from which to assume that disturbance of ecosystems byfire has led to strong selective processes not only among plants, but also among invertebrates, since the intermediate fire levels which are characteristic for today are still well above the natural fire frequency. Although these forest communities appear to be quite resilient to fire, prescribed burning cannot be advocated as a preventative measure to avoid intensive crown fires. Most fires occur in the springtime, when the deciduous broadleaved trees have no leaves, limiting the risk of crown fires. However, even low intensity fires increase the risk of more run-off erosion, which is ahighly undesirable effect in the densely inhabited and steep hilly region south of the Alps (Marxer 2003; Conedera et al. 2003).

The cultivation of chestnut forests as coppice for timber production started in most parts of Europe with the Romans, who also introduced the tree species itself. Thus, coppices of chestnut forests were managed intensively for about 2,000 years. In most countries with a long tradition of chestnut cultivation, chestnut coppices were cut in a 15- to 20-year rotation for pole, firewood and charcoal production (Conedera et al. 2004a, b). However, in southern Switzerland the traditional chestnut coppices have mostly been abandoned since the 1960s (Conedera et al. 2001). We suggest reconsidering coppicing chestnut forests on small areas and leaving part of the dead wood in the field to mimic frequent disturbances of low intensity. The conservation of tracts of intact forests should provide suitable biotopes for late successional organisms, which require dead and old wood and generally stable conditions.

Informed management of chestnut forests requires an understanding of ecosystem resilience. While Baker et al. (2004) found little difference between the beetle fauna after logging or wildfire treatments in Tasmanian forests, Buddle et al. (2000) and Saint-Germain et al. (2005) observed a significant divergence in spiders' and carabid beetles' responses to such disturbancesin boreal forests. Could patch-wise clearfelling and harvesting be a way of preserving a fire-adapted biodiversity without the negative effects of forest fires (emissions and erosion), and at the same time allow for the production of valuable chestnut timber? If attempts are made to imitate a natural disturbance such as a forest fire through forest management and interventions, like harvesting timber in small-scale coppice groves, they must take into account the recovery times of func- 
tionality and biodiversity to allow for a multifunctional, but still sustainable, form of management.

Acknowledgements We are grateful to M. Conedera, K. Schiegg, W. Tinner, H. Wagner and P. Pearman for useful comments on the manuscript and discussion of the results. We also thank C. Staehli for helping with data analysis, and S. Dingwall for helping to revise the manuscript. Many thanks are due to

Table 3 a-f Transient or non-transient changes in dominance at the species level. Median value of relative abundance (dominance) in the different functional groups at the unburnt site (control) and the successional stages $(<1,1-3,6-14$, the people who helped with the fieldwork (P. Hördegen, P. Wirz, F. Fibbioli, and K. Sigrist) and who identified or checked the species (F. Amiet, S. Barbalat, R. Bärfuss, C. Besuchet, C. Germann, I. Giacalone, A. Hänggi, X. Heer, P. Hördegen, P. Stucky, D. Wyniger, and P. Zahradnik).

\section{Appendix (Tables 3, 4)}

17-24 years) after single and repeated fires (dominance: (big filled circle $) \geq 10 \%$, (big open circle) $3.2-9.9 \%,+1.0-3.1 \%$, (small filled circle) $<1 \%,-0 \%$ )

10a) Epigaeic zoophages

\begin{tabular}{|c|c|c|c|c|c|c|c|c|c|c|}
\hline \multirow[b]{2}{*}{ Species } & \multirow{2}{*}{$\begin{array}{c}\text { Systematic } \\
\text { group }\end{array}$} & \multirow{2}{*}{ Unburnt } & \multicolumn{4}{|c|}{ Single fire } & \multicolumn{4}{|c|}{ Repeated fires } \\
\hline & & & $<1$ & $1-3$ & $6-14$ & $17-24$ & $<1$ & $1-3$ & $6-14$ & $17-24$ \\
\hline Dienerella clathrata & Col & 0 & $\mathrm{O}$ & O & 0 & O & 0 & + & $\mathrm{O}$ & $\mathrm{O}$ \\
\hline Lasius emarginatus & For & 0 & 0 & 0 & $\mathrm{O}$ & 0 & O & 0 & ○ & 0 \\
\hline Leptothorax nylanderi & For & 0 & - & + & 0 & O & - & - & + & $\bullet$ \\
\hline Pterostichus micans & Col & O & - & + & O & O & $\bullet$ & $\bullet$ & $\mathrm{O}$ & 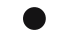 \\
\hline Abax continuus & Col & O & + & + & $\mathrm{O}$ & $\mathrm{O}$ & + & 0 & + & O \\
\hline Aphaenogaster subterranea & For & O & - & + & 0 & + & $\bullet$ & + & 0 & $\bullet$ \\
\hline Corticaria ferruginea & Col & - & - & $\bullet$ & - & $\bullet$ & $\bullet$ & - & $\bullet$ & - \\
\hline Stenamma debile & For & $\bullet$ & O & + & - & $\bullet$ & O & $\bullet$ & $\bullet$ & $\bullet$ \\
\hline Lepthyphantes pall. pallidus & Ara & $\bullet$ & O & + & - & + & + & - & + & + \\
\hline Tegenaria fuesslini & Ara & + & O & + & + & + & + & + & + & + \\
\hline Lasius platythorax & For & + & O & $\bullet$ & - & $\bullet$ & + & O & + & - \\
\hline Carabus glabratus & Col & - & + & O & - & - & - & $\bullet$ & - & - \\
\hline Diplostyla concolor & Ara & $\bullet$ & $\bullet$ & O & $\bullet$ & $\bullet$ & - & $\bullet$ & $\bullet$ & - \\
\hline Leptothorax parvulus & For & + & - & $\bullet$ & 0 & 0 & - & $\bullet$ & $\bullet$ & $\bullet$ \\
\hline Carabus problematicus & Col & + & + & - & $\mathrm{O}$ & $\mathrm{O}$ & + & + & - & + \\
\hline Pardosa saltans & Ara & + & $\bullet$ & $\bullet$ & O & O & - & O & $\mathrm{O}$ & $\mathrm{O}$ \\
\hline Forica fusca & For & + & + & ○ & + & O & - & O & + & O \\
\hline Abax baenningeri & Col & + & + & $\bullet$ & + & $\mathrm{O}$ & + & $\bullet$ & 0 & + \\
\hline Myrmica ruginodis & For & - & - & - & - & + & - & 0 & 0 & - \\
\hline Lasius psammophilus & For & $\bullet$ & - & + & - & - & - & + & • & O \\
\hline Amaurobius jugorum & Ara & - & • & + & - & + & + & $\bullet$ & + & 0 \\
\hline Leptothorax unifasciatus & For & $\bullet$ & - & - & + & + & - & - & $\bullet$ & 0 \\
\hline Total dominant species & O & 3 & 2 & 2 & 4 & 2 & 2 & 2 & 3 & 1 \\
\hline Total subdominant species & $\mathrm{O}$ & 3 & 5 & 3 & 5 & 8 & 2 & 4 & 4 & 8 \\
\hline
\end{tabular}

b) Saproxylophages

\begin{tabular}{|c|c|c|c|c|c|c|c|c|c|c|}
\hline \multirow[b]{2}{*}{ Species } & \multirow{2}{*}{$\begin{array}{c}\begin{array}{c}\text { Systematic } \\
\text { group }\end{array} \\
\end{array}$} & \multirow{2}{*}{ Unburnt } & \multicolumn{4}{|c|}{ Single fire } & \multicolumn{4}{|c|}{ Repeated fires } \\
\hline & & & $<1$ & $1-3$ & $6-14$ & $17-24$ & $<1$ & $1-3$ & $6-14$ & $17-24$ \\
\hline Dienerella clathrata & $\mathrm{Col}$ & O & $\mathrm{O}$ & 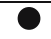 & O & O & $\bullet$ & $\mathrm{O}$ & 0 & 0 \\
\hline Ptinus bidens & Col & 0 & - & $\bullet$ & 0 & O & - & O & + & $\mathrm{O}$ \\
\hline Lathridius nodifer & Col & $\mathrm{O}$ & - & O & + & O & + & + & $\mathrm{O}$ & $\mathrm{O}$ \\
\hline Xyleborinus saxesenii & Col & - & $\bullet$ & O & $\bullet$ & $\bullet$ & - & + & $\bullet$ & + \\
\hline Coxelus pictus & Col & $\bullet$ & $\bullet$ & $\bullet$ & $\bullet$ & $\bullet$ & $\bullet$ & $\bullet$ & $\mathrm{O}$ & O \\
\hline Magdalis cerasi & Col & $\bullet$ & $\bullet$ & + & $\bullet$ & + & $\bullet$ & O & $\bullet$ & + \\
\hline Xyleborus dispar & $\mathrm{Col}$ & $\bullet$ & - & + & $\bullet$ & + & - & + & + & O \\
\hline Corticaria ferruginea & Col & $\bullet$ & 0 & $\bullet$ & - & $\bullet$ & - & $\bullet$ & $\bullet$ & - \\
\hline Xylota segnis & Syr & $\bullet$ & 0 & $\bullet$ & $\bullet$ & $\bullet$ & O & O & $\bullet$ & - \\
\hline Oedemera flavipes & $\mathrm{Col}$ & - & 0 & $\bullet$ & $\bullet$ & $\bullet$ & + & - & $\bullet$ & + \\
\hline Isomira murina & $\mathrm{Col}$ & $\bullet$ & - & - & $\bullet$ & O & & $\bullet$ & $\bullet$ & + \\
\hline Leptura maculata & $\mathrm{Col}$ & - & + & + & $\bullet$ & $\bullet$ & + & O & + & $\bullet$ \\
\hline Chlorophorus figuratus & $\mathrm{Col}$ & - & $\bullet$ & - & - & - & $\bullet$ & O & $\bullet$ & - \\
\hline Acalles roboris & Col & + & - & $\bullet$ & + & + & + & $\bullet$ & O & O \\
\hline Aneurus laevis & Het & $\bullet$ & - & - & $\bullet$ & $\bullet$ & - & $\bullet$ & $\bullet$ & O \\
\hline Total dominant species & O & 2 & 1 & 2 & 2 & 2 & 2 & 1 & 1 & 1 \\
\hline Total subdominant species & $\mathrm{O}$ & 1 & 3 & 2 & 0 & 2 & 1 & 6 & 3 & 6 \\
\hline
\end{tabular}


Table 3 continued

c) Ground-litter saprophages

\begin{tabular}{|c|c|c|c|c|c|c|c|c|c|c|}
\hline \multirow[b]{2}{*}{ Species } & \multirow{2}{*}{$\begin{array}{c}\text { Systematic } \\
\text { group }\end{array}$} & \multirow{2}{*}{ Unburnt } & \multicolumn{4}{|c|}{ Single fire } & \multicolumn{4}{|c|}{ Repeated fires } \\
\hline & & & $<1$ & $1-3$ & $6-14$ & $17-24$ & $<1$ & $1-3$ & $6-14$ & $17-24$ \\
\hline Leptothorax nylanderi & For & ○ & - & 0 & 0 & 0 & + & + & O & + \\
\hline Leptothorax parvulus & For & O & - & + & O & ○ & $\bullet$ & + & O & + \\
\hline Stenamma striatulum & For & $\mathrm{O}$ & + & + & $\bullet$ & $\mathrm{O}$ & $\bullet$ & $\mathrm{O}$ & $\bullet$ & $\bullet$ \\
\hline Trichoniscus alemannicus & Iso & ○ & O & - & + & + & 0 & + & + & ○ \\
\hline Stenamma debile & For & + & 0 & 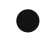 & - & + & 0 & + & + & $\bullet$ \\
\hline Tiroloscia exigua & Iso & $\bullet$ & - & $\bullet$ & - & $\bullet$ & 0 & - & $\bullet$ & - \\
\hline Cylisticus bieliensis & Iso & $\bullet$ & O & 0 & $\bullet$ & $\bullet$ & 0 & $\bullet$ & $\bullet$ & + \\
\hline Lepidoniscus pruinosus & Iso & + & 0 & - & - & + & + & - & 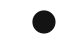 & 0 \\
\hline Lasius umbratus & For & $\bullet$ & O & + & - & $\bullet$ & $\bullet$ & $\bullet$ & $\bullet$ & - \\
\hline Tetramorium caespitum & For & $\bullet$ & O & + & - & $\bullet$ & $\bullet$ & + & $\bullet$ & - \\
\hline Pseudophonus rufipes & Col & - & O & $\bullet$ & - & - & - & $\bullet$ & $\bullet$ & - \\
\hline Notiophilus biguttatus & Col & $\bullet$ & + & 0 & - & $\bullet$ & 0 & - & - & - \\
\hline Cryptophagus sp. & Col & $\bullet$ & - & 0 & + & - & - & $\bullet$ & $\bullet$ & + \\
\hline Nicrophorus vespilloides & Col & $\bullet$ & - & 0 & $\bullet$ & $\bullet$ & - & + & $\bullet$ & + \\
\hline Geotrupes niger & Col & $\bullet$ & + & O & - & - & - & - & $\bullet$ & - \\
\hline Nicrophorus humator & Col & $\bullet$ & + & 0 & $\bullet$ & $\bullet$ & - & $\bullet$ & $\bullet$ & - \\
\hline Nicrophorus investigator & Col & $\bullet$ & - & 0 & - & - & - & 0 & $\bullet$ & O \\
\hline Leptothorax unifasciatus & For & + & - & - & O & O & - & 0 & O & ○ \\
\hline Myrmica ruginodis & For & $\bullet$ & - & - & + & O & - & - & 0 & - \\
\hline Orthometopon planum & Iso & + & + & $\bullet$ & + & + & - & + & O & - \\
\hline Myrmica sabuleti & For & $\bullet$ & - & - & + & $\bullet$ & $\bullet$ & O & O & + \\
\hline Myrmecina graminicola & For & + & - & - & - & - & - & O & $\bullet$ & $\bullet$ \\
\hline Sciodrepoides watsoni & Col & - & - & - & - & - & - & $\mathrm{O}$ & - & - \\
\hline Total dominant species & 0 & 1 & 2 & 2 & 2 & 2 & 3 & 1 & 2 & 3 \\
\hline Total subdominant species & $\mathrm{O}$ & 3 & 5 & 7 & 1 & 3 & 2 & 6 & 5 & 2 \\
\hline
\end{tabular}

5d) Phytophages

\begin{tabular}{|c|c|c|c|c|c|c|c|c|c|c|}
\hline \multirow[b]{2}{*}{ Species } & \multirow{2}{*}{$\begin{array}{c}\text { Systematic } \\
\text { group }\end{array}$} & \multirow{2}{*}{ Unburnt } & \multicolumn{4}{|c|}{ Single fire } & \multicolumn{4}{|c|}{ Repeated fires } \\
\hline & & & $<1$ & $1-3$ & $6-14$ & $17-24$ & $<1$ & $1-3$ & $6-14$ & $17-24$ \\
\hline Attelabus nitens & $\mathrm{Col}$ & O & O & 0 & 0 & 0 & 0 & 0 & 0 & 0 \\
\hline Polydrusus marginatus & Col & 0 & 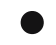 & - & O & 0 & 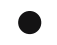 & 0 & O & 0 \\
\hline Kleidocerys resedae & Het & 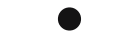 & $\bullet$ & O & O & $\bullet$ & - & $\bullet$ & + & O \\
\hline Strophosoma melanogrammum & Col & O & - & $\bullet$ & O & + & $\bullet$ & 0 & ○ & O \\
\hline Otiorhynchus difficilis & Col & $\mathrm{O}$ & - & + & 0 & $\mathrm{O}$ & - & $\bullet$ & O & 0 \\
\hline Polydrusus cervinus & Col & + & O & O & O & O & 0 & + & + & O \\
\hline Phyllobius argentatus & Col & + & 0 & O & 0 & + & 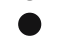 & - & O & - \\
\hline Homorhythmus hirticornis & $\mathrm{Col}$ & + & O & O & O & + & + & $\bullet$ & $\bullet$ & + \\
\hline Dicyphus errans & Het & - & O & O & - & - & + & - & - & - \\
\hline Magdalis cerasi & Col & + & $\bullet$ & 0 & - & + & $\bullet$ & 0 & $\bullet$ & + \\
\hline Magdalis flavicornis & Col & - & - & O & + & $\bullet$ & - & + & + & + \\
\hline Dicyphus flavoviridis & Het & - & - & 0 & - & - & - & - & - & - \\
\hline Scolopostethus cognatus & Het & $\bullet$ & - & - & O & - & - & - & - & - \\
\hline Rhynchaenus rusci & Col & - & • & - & - & 0 & + & + & - & + \\
\hline Lasiorhynchites sericeus & Col & $\bullet$ & - & $\bullet$ & - & $\bullet$ & O & + & $\bullet$ & $\bullet$ \\
\hline Total dominant species & 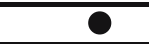 & 3 & 3 & 1 & 1 & 2 & 4 & 1 & 2 & 2 \\
\hline Total subdominant species & $\mathrm{O}$ & 2 & 3 & 8 & 7 & 3 & 0 & 3 & 3 & 4 \\
\hline
\end{tabular}


Table 3 continued

e) Pollinophages

\begin{tabular}{|c|c|c|c|c|c|c|c|c|c|c|}
\hline \multirow[b]{2}{*}{ Species } & \multirow{2}{*}{$\begin{array}{c}\text { Systematic } \\
\text { group }\end{array}$} & \multirow{2}{*}{ Unburnt } & \multicolumn{4}{|c|}{ Single fire } & \multicolumn{4}{|c|}{ Repeated fires } \\
\hline & & & $<1$ & $1-3$ & $6-14$ & $17-24$ & $<1$ & $1-3$ & $6-14$ & $17-24$ \\
\hline Andrena minutula & Apo & 0 & $\mathrm{O}$ & 0 & 0 & 0 & $\mathrm{O}$ & 0 & 0 & 0 \\
\hline Dienerella clathrata & Col & 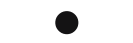 & + & 0 & 0 & 0 & 0 & + & 0 & 0 \\
\hline Apis mellifera & Apo & 0 & + & 0 & 0 & 0 & + & 0 & 0 & 0 \\
\hline Lasioglossum minutulum & Apo & O & $\mathrm{O}$ & O & O & O & + & O & O & + \\
\hline Andrena fulvata & Apo & 0 & $\bullet$ & + & $\bullet$ & 0 & + & $\bullet$ & $\bullet$ & $\bullet$ \\
\hline Lasioglossum morio & Apo & + & 0 & O & $\bullet$ & O & 0 & 0 & O & - \\
\hline Hylaeus communis & Apo & - & 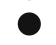 & O & $\bullet$ & - & 0 & + & 0 & - \\
\hline Corticaria ferruginea & Col & $\bullet$ & - & $\bullet$ & - & $\bullet$ & 0 & $\bullet$ & $\bullet$ & - \\
\hline Lasioglossum laticeps & Apo & + & 0 & + & - & + & 0 & + & - & + \\
\hline Lasioglossum pygmaeum & Apo & - & 0 & $\bullet$ & $\bullet$ & $\bullet$ & 0 & $\bullet$ & - & - \\
\hline Melangyna lasiophthalma & Syr & + & - & O & + & + & $\bullet$ & $\bullet$ & + & - \\
\hline Lasioglossum fulvicorne & Apo & + & • & + & 0 & + & - & + & + & + \\
\hline Bombus pascuorum & Apo & + & + & + & O & + & $\bullet$ & + & + & + \\
\hline Andrena helvola & Apo & + & $\bullet$ & + & $\bullet$ & $\mathrm{O}$ & + & 0 & $\bullet$ & + \\
\hline Forica fusca & For & + & $\bullet$ & + & + & O & $\bullet$ & 0 & + & O \\
\hline Lasioglossum politum & Apo & + & - & - & + & + & - & 0 & O & 0 \\
\hline Oedemera flavipes & $\mathrm{Col}$ & $\bullet$ & + & $\bullet$ & $\bullet$ & $\bullet$ & • & 0 & $\bullet$ & $\bullet$ \\
\hline Andrena dorsata & Apo & + & $\bullet$ & + & + & + & $\bullet$ & + & O & + \\
\hline Lasius psammophilus & For & - & - & $\bullet$ & & - & - & + & $\bullet$ & 0 \\
\hline Total dominant species & O & 3 & 3 & 1 & 2 & 2 & 3 & 3 & 1 & 3 \\
\hline Total subdominant species & $\mathrm{O}$ & 2 & 4 & 5 & 5 & 6 & 4 & 5 & 7 & 4 \\
\hline
\end{tabular}

5f) Flying zoophages

\begin{tabular}{|c|c|c|c|c|c|c|c|c|c|c|}
\hline \multirow[b]{2}{*}{ Species } & \multirow{2}{*}{$\begin{array}{c}\text { Systematic } \\
\text { group }\end{array}$} & \multirow{2}{*}{ Unburnt } & \multicolumn{4}{|c|}{ Single fire } & \multicolumn{4}{|c|}{ Repeated fires } \\
\hline & & & $<1$ & $1-3$ & $6-14$ & $17-24$ & $<1$ & $1-3$ & $6-14$ & $17-24$ \\
\hline Melangyna lasiophthalma & Syr & 0 & - & O & $\mathrm{O}$ & 0 & - & + & $\mathrm{O}$ & + \\
\hline Panorpa communis & $\mathrm{Neu}$ & 0 & + & 0 & 0 & 0 & + & + & 0 & 0 \\
\hline Semidalis aleyrodiForis & $\mathrm{Neu}$ & O & - & - & 0 & $\mathrm{O}$ & $\bullet$ & - & + & 0 \\
\hline Vespula vulgaris & Hym & 0 & + & + & 0 & 0 & + & + & + & $\mathrm{O}$ \\
\hline Deraeocoris lutescens & Het & O & $\bullet$ & + & 0 & + & $\bullet$ & $\bullet$ & $\bullet$ & + \\
\hline Chrysoperla carnea & $\mathrm{Neu}$ & O & 0 & 0 & 0 & + & + & + & + & . \\
\hline Crossocerus quadrimaculatus & Hym & + & O & + & O & O & O & O & + & O \\
\hline Orius horvathi & Het & - & O & + & $\bullet$ & $\bullet$ & 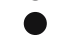 & $\bullet$ & - & $\bullet$ \\
\hline Sphaerophoria scripta & Syr & $\bullet$ & O & + & - & - & + & + & $\bullet$ & $\bullet$ \\
\hline Hemerobius humulinus & $\mathrm{Neu}$ & - & O & + & - & - & + & + & + & + \\
\hline Hemerobius micans & $\mathrm{Neu}$ & + & O & + & + & + & + & $\bullet$ & + & + \\
\hline Passaloecus corniger & Hym & $\bullet$ & O & $\bullet$ & $\bullet$ & $\bullet$ & + & $\bullet$ & + & $\bullet$ \\
\hline Passaloecus insignis & Hym & + & 0 & $\bullet$ & - & + & 0 & + & 0 & - \\
\hline Spilomena troglodytes & Hym & + & O & + & O & + & + & O & + & + \\
\hline Dicyphus errans & Het & - & + & 0 & - & $\bullet$ & + & $\bullet$ & - & - \\
\hline Crossocerus annulipes & Hym & $\bullet$ & + & O & - & $\bullet$ & - & - & $\bullet$ & - \\
\hline EpiSyrus balteatus & Syr & + & + & O & $\bullet$ & + & O & + & + & $\mathrm{O}$ \\
\hline Harpocera thoracica & Het & + & $\bullet$ & $\bullet$ & + & 0 & 0 & 0 & $\bullet$ & 0 \\
\hline Priocnemis perturbator & Hym & + & + & $\bullet$ & $\bullet$ & + & $\bullet$ & O & + & 0 \\
\hline Psenulus pallipes & Hym & - & + & + & + & $\bullet$ & - & + & O & + \\
\hline Trypoxylon minus & Hym & $\bullet$ & + & - & $\bullet$ & $\bullet$ & $\bullet$ & + & O & $\bullet$ \\
\hline Syrus torvus & Syr & + & - & + & - & + & + & + & 0 & - \\
\hline Vespula rufa & Hym & $\bullet$ & - & & - & + & & - & $\bullet$ & O \\
\hline Total dominant species & 0 & 2 & 0 & 1 & 3 & 1 & 1 & 0 & 1 & 1 \\
\hline Total subdominant species & $\mathrm{O}$ & 4 & 9 & 5 & 5 & 5 & 4 & 4 & 5 & 7 \\
\hline
\end{tabular}

Changes by the dominant $(\geq 10 \%)$ and subdominant (3.2-9.9\%) species have to be interpret as major/important change/alteration within a community

Systematic groups: Ara Aranea, Col Coleoptera, For Formicidae, Het Hetereptera, Iso Isopoda, Neu Neuroptera, Syr Syrphidae 
Table 4 Species whose abundances were significantly affected in the short or long term by single or repeated fires. Mean number of individuals per trap site of fire-affected species varied tenfold either shortly after the fire ( $<1$ year) or at the last successional stage (17-24 years after the last fire). The mean values were tested by ANOVA or non-parametric Mann-Whitney U-test if homogeneity of variance was not achieved

\begin{tabular}{|c|c|c|c|c|c|c|c|c|c|c|c|c|}
\hline \multirow[t]{2}{*}{ Functional group } & \multirow[t]{2}{*}{ Species } & \multirow{2}{*}{$\begin{array}{l}\text { Systematic } \\
\text { group }\end{array}$} & \multirow{2}{*}{$\begin{array}{l}\text { Total } \\
\text { ind. }\end{array}$} & \multirow{2}{*}{$\begin{array}{l}\text { Unburnt }> \\
30 \text { years }\end{array}$} & \multicolumn{4}{|c|}{ Single fire } & \multicolumn{4}{|c|}{ Repeated fires } \\
\hline & & & & & \multicolumn{2}{|c|}{$<1$ year } & \multicolumn{2}{|c|}{$\begin{array}{l}17-24 \\
\text { years }\end{array}$} & \multicolumn{2}{|c|}{$<1$ year } & \multicolumn{2}{|l|}{$\begin{array}{l}17-24 \\
\text { years }\end{array}$} \\
\hline \multicolumn{13}{|l|}{ Species favoured by fire } \\
\hline \multirow[t]{10}{*}{ Pollinophages } & Hylaeus communis & Hym & 1,489 & 0.5 & 132.0 & $* * *$ & 1.8 & n.s. & 121.7 & $* * *$ & 0.3 & n.s. \\
\hline & Hylaeus gibbus & Hym & 183 & 0.2 & 3.7 & $* * *$ & 0.6 & n.s. & 2.7 & $* *$ & 2.3 & $*$ \\
\hline & Lasioglossum morio & Hym & 4,738 & 18.4 & 108.3 & $*$ & 21.4 & n.s. & 118.3 & $*$ & 223.0 & $* * *$ \\
\hline & Lasioglossum pygmaeum & Hym & 592 & 2.3 & 75.7 & $* * *$ & 1.8 & n.s. & 65.7 & $* * *$ & 1.0 & n.s. \\
\hline & Lasioglossum rufitarse & Hym & 92 & 0.2 & 7.3 & $* *$ & 0.4 & n.s. & 5.0 & $*$ & 0.0 & n.s. \\
\hline & Melanostoma scalare & Syr & 49 & 0.2 & 6.0 & $* *$ & 0.7 & n.s. & 3.7 & ** & 0.7 & n.s. \\
\hline & Platycheirus scutatus & Syr & 70 & 0.4 & 6.0 & $* *$ & 1.3 & n.s. & 6.3 & ** & 0.0 & n.s. \\
\hline & Sphaerophoria scripta & Syr & 103 & 0.2 & 13.3 & $* *$ & 0.0 & n.s. & 7.7 & $*$ & 0.3 & n.s. \\
\hline & Xylota segnis & Syr & 393 & 0.7 & 16.0 & $* * *$ & 1.0 & n.s. & 14.7 & $* * *$ & 0.0 & n.s. \\
\hline & Oedemera flavipes & $\mathrm{Col}$ & 437 & 0.3 & 8.7 & $* *$ & 0.1 & n.s. & 3.3 & $* *$ & 1.0 & n.s. \\
\hline \multirow{8}{*}{ Saproxylophages } & Anthrenus museorum & Col & 24 & 0.0 & 0.3 & $*$ & 0.0 & n.s. & 7.7 & $* * *$ & 0.0 & n.s. \\
\hline & Corticaria ferruginea & Col & 579 & 0.7 & 86.7 & $* * *$ & 1.0 & n.s. & 92.7 & $* * *$ & 0.0 & n.s. \\
\hline & Corticarina similata & Col & 20 & 0.0 & 2.3 & $*$ & 0.0 & n.s. & 3.7 & * & 0.0 & n.s. \\
\hline & Leptura maculata & Col & 142 & 0.3 & 4.3 & $* *$ & 0.7 & n.s. & 3.0 & n.s. & 0.7 & n.s. \\
\hline & Stenopterus rufus & Col & 79 & 0.0 & 4.7 & $*$ & 0.0 & n.s. & 3.7 & * & 0.0 & n.s. \\
\hline & Dicyphus errans & Het & 70 & 0.1 & 4.0 & $*$ & 0.1 & n.s. & 3.0 & * & 0.0 & n.s. \\
\hline & Harpocera thoracica & Het & 286 & 1.4 & 1.3 & n.s. & 14.1 & $* *$ & 14.0 & $* * *$ & 6.7 & n.s. \\
\hline & Orius horvathi & Het & 179 & 0.0 & 16.0 & $* * *$ & 0.1 & n.s. & 32.3 & $* * *$ & 0.3 & n.s. \\
\hline \multirow[t]{4}{*}{ Flying zoophages } & Passaloecus corniger & Hym & 104 & 0.5 & 6.7 & $* *$ & 0.1 & n.s. & 7.0 & $* *$ & 0.3 & n.s. \\
\hline & Passaloecus gracilis & Hym & 58 & 0.2 & 4.7 & $* *$ & 0.4 & n.s. & 1.7 & n.s. & 0.3 & n.s. \\
\hline & Passaloecus insignis & Hym & 207 & 1.2 & 7.3 & $* *$ & 2.1 & n.s. & 12.0 & $* *$ & 0.7 & n.s. \\
\hline & Pemphredon inornata & Hym & 75 & 0.1 & 2.0 & $* *$ & 0.4 & n.s. & 5.0 & $* * *$ & 0.7 & n.s. \\
\hline Phytophages & Lasiorhynchites sericeus & Col & 97 & 0.7 & 3.7 & $*$ & 1.4 & n.s. & 11.7 & $* *$ & 1.0 & n.s. \\
\hline & Phyllobius argentatus & Col & 523 & 3.8 & 46.0 & $* * *$ & 3.1 & n.s. & 52.3 & $* * *$ & 0.0 & n.s. \\
\hline Species negatively affect & by fire & & & & & & & & & & & \\
\hline Epigaeic zoophages & Coelotes mediocris & Ara & 136 & 4.2 & 0.0 & $*$ & 1.2 & n.s. & 0.0 & $*$ & 0.0 & ** \\
\hline & Lepthyphantes flavipes & Ara & 556 & 11.9 & 1.0 & $*$ & 8.9 & n.s. & 1.7 & * & 5.0 & n.s. \\
\hline & Tapinocyba maureri & Ara & 229 & 5.8 & 0.3 & n.s. & 6.1 & n.s. & 0.0 & n.s. & 4.3 & n.s. \\
\hline & Trochosa hispanica & Ara & 525 & 5.5 & 0.0 & $*$ & 4.3 & n.s. & 0.3 & $*$ & 6.7 & n.s. \\
\hline & Aphaenogaster subterranea & Hym & 1,768 & 41.3 & 0.0 & * & 19.6 & n.s. & 0.7 & ** & 1.7 & * \\
\hline & Leptothorax nylanderi & Hym & 5,066 & 206.1 & 0.0 & * & 57.9 & $*$ & 0.7 & **** & 1.0 & $* * *$ \\
\hline & Leptothorax parvulus & Hym & 1,404 & 17.5 & 0.0 & $*$ & 50.3 & n.s. & 0.3 & * & 0.7 & * \\
\hline & Leptothorax unifasciatus & Hym & 426 & 7.3 & 0.0 & n.s. & 15.3 & $*$ & 0.0 & n.s. & 12.0 & n.s. \\
\hline & Myrmecina graminicola & Hym & 147 & 4.6 & 0.0 & $*$ & 1.2 & n.s. & 0.0 & * & 0.3 & * \\
\hline & Stenamma striatulum & Hym & 342 & 11.7 & 0.3 & * & 7.1 & n.s. & 0.3 & * & 0.3 & * \\
\hline & Pterostichus micans & $\mathrm{Col}$ & 2,328 & 52.0 & 0.0 & ** & 58.6 & n.s. & 2.3 & * & 50.0 & n.s. \\
\hline Pollinophages & Andrena dorsata & Hym & 962 & 12.4 & 0.3 & $*$ & 9.2 & n.s. & 2.0 & * & 19.0 & n.s. \\
\hline & Andrena fulvata & Hym & 1,018 & 28.6 & 1.7 & $*$ & 21.8 & n.s. & 20.7 & n.s. & 0.3 & * \\
\hline & Andrena haemorrhoa & Hym & 380 & 5.7 & 0.3 & * & 5.0 & n.s. & 0.3 & $*$ & 3.3 & n.s. \\
\hline & Andrena nigroaenea & Hym & 248 & 5.5 & 0.3 & $* *$ & 1.9 & $* *$ & 0.0 & $* *$ & 2.7 & n.s. \\
\hline & Apis mellifera & Hym & 4,588 & 132.9 & 13.3 & n.s. & 27.8 & n.s. & 18.3 & n.s. & 38.0 & n.s. \\
\hline & Bombus hypnorum & Hym & 224 & 4.0 & 0.3 & $*$ & 3.0 & n.s. & 0.7 & $*$ & 2.7 & n.s. \\
\hline & Lasioglossum fulvicorne & Hym & 732 & 10.4 & 4.3 & n.s. & 8.4 & n.s. & 1.0 & * & 11.3 & n.s. \\
\hline & Lasioglossum politum & Hym & 1,993 & 15.0 & 0.0 & ** & 8.8 & n.s. & 0.7 & * & 97.7 & $* *$ \\
\hline & Melangyna lasiophthalma & Syr & 864 & 15.8 & 0.0 & $*$ & 14.9 & n.s. & 2.0 & * & 2.3 & n.s. \\
\hline Ground-litter saprophages & Dienerella clathrata & $\mathrm{Col}$ & 5,065 & 156.1 & 11.0 & $*$ & 68.2 & $*$ & 33.0 & $* *$ & 22.0 & $* *$ \\
\hline & Enicmus minutus & Col & 81 & 3.8 & 0.0 & $*$ & 0.2 & n.s. & 0.0 & $*$ & 0.0 & $*$ \\
\hline & Lathridius nodifer & Col & 467 & 10.4 & 0.7 & $* *$ & 8.1 & n.s. & 2.3 & * & 4.0 & n.s. \\
\hline & Orthometopon planum & Iso & 237 & 3.9 & 0.3 & n.s. & 3.7 & n.s. & 0.3 & n.s. & 5.3 & n.s. \\
\hline Phytophages & Kleidocerys resedae & Het & 679 & 31.4 & 1.0 & n.s. & 1.0 & n.s. & 0.3 & n.s. & 5.0 & n.s. \\
\hline & Otiorhynchus difficilis & Col & 347 & 6.6 & 1.0 & $*$ & 8.3 & n.s. & 0.0 & $*$ & 3.7 & $*$ \\
\hline Flying zoophages & Semidalis aleyrodiforis & $\mathrm{Neu}$ & 405 & 8.9 & 0.3 & * & 8.3 & n.s. & 0.7 & * & 5.7 & n.s. \\
\hline Saproxylophages & Ptinus bidens & $\mathrm{Col}$ & 1,293 & 37.3 & 0.3 & $* *$ & 33.9 & n.s. & 0.0 & * & 3.0 & $*$ \\
\hline
\end{tabular}

$* P \leq 0.5, * * P \leq 0.01, * * * P \leq 0.001, n . s$. not significant

Total ind. Total number of individuals sampled in the 66 trap sites, Hym Hymenoptera, Syr Syrphidae,Col Coleoptera, Het Hetereptera, Ara Aranea, Iso Isopoda, Neu Neuroptera 


\section{References}

Baker SC, Richardson AMM, Seeman DO, Barmuta LA (2004) Does clearfell, burn and sow silviculture mimic the effect of wildfire? A field study and review using litter beetles. For Ecol Manage 199:433-448

Begon M, Harper JL, Townsend CR (1999) Ecology. Blackwell, Berlin

Bengtsson J (1998) Which species? What kind of diversity? Which ecosystem function? Some problems in studies of relations between biodiversity and ecosystem function. Appl Soil Ecol 10:191-199

Bengtsson J (2002) Disturbance and resilience in soil animal communities. Eur J Soil Biol 38:119-125

Bengtsson J, Nilsson SG, Franc A, Menozzi P (2000) Biodiversity, disturbance, ecosystem function and management of European forests. For Ecol Manag 132:39-50

Bense U (1995) Longhorn beetles. Illustrated key to the Cerambycidae and Vesperidae of Europe. Margraf, Weikersheim

Brunhes J (1981) Caractéristiques et performances d'un pièges à émergence destiné à l'étude des Insectes à larves édaphiques ou aquatiques. Entomologiste 37:126-131

Buddle CM, Spence JR, Langor DW (2000) Succession of boreal forest spider assemblages following wildfire and harvesting. Ecography 23:424-436

Collins SL, Glenn SM, Gibson DJ (1995) Experimental-analysis of Intermediate disturbance hypothesis and initial floristic composition—decoupling cause and effect. Ecology 76:486492

Conedera M, Manetti MC, Giudici F, Amorini E (2004a) Distribution and economic potential of the sweet chestnut (Castanea sativa Mill.) in Europe. Ecol Mediterr 30:179-193

Conedera M, Stanga P, Oester B, Bachmann P (2001) Different post-culture dynamics in abandoned chestnut orchards. For Snow Landsc Res 76:487-492

Conedera M, Krebs P, Tinner W, Pradella M, Torriani D (2004b) The cultivation of Castanea sativa (Mill.) in Europe, from its origin to its diffusion on a continental scale. Veg Hist Archaeobot 13:161-179

Conedera M, Peter L, Marxer P, Forster F, Rickenmann D, Re L (2003) Consequences of forest fires on the hydrogeological response of mountain catchments: a case study of the Riale Buffaga, Ticino, Switzerland. Earth Surf Process Land 28:117-129

Connell HV (1978) Diversity in tropical rain forests and coral reefs. Science 199:1302-1310

Crailsheim K, Schneider LHW, Hrassnigg N, Buhlmann G, Brosch U, Gmeinbauer R, Schoffmann B (1992) Pollen consumption and utilization in worker honeybees (Apis mellifera carnica) dependence on individual age and function. J Insect Physiol 38:409-419

Dajoz R (2000) Insects and forests. Intercept Lavoisier, Paris

Debinski DM, Ray C, Saveraid EH (2001) Species diversity and the scale of the landscape mosaic: do scales of movement and patch size affect diversity? Biol Conserv 98:179-190

Duelli P (1997) Biodiversity evaluation in agricultural landscapes: an approach at two different scales. Agric Ecosyst Environ 62:81-91

Duelli P, Obrist MK, Schmatz DR (1999) Biodiversity evaluation in agricultural landscapes: above-ground insects. Agric Ecosyst Environ 74:33-64

Forman RTT, Gordon M (1986) Landscape ecology. Wiley, New York
Hanula JL, Wade DD (2003) Influence of long-term dormantseason burning and fire exclusion on ground-dwelling arthropod populations in longleaf pine flatwoods ecosystems. For Ecol Manage 175:163-184

Haydon DT, Friar JK, Pianka ER (2000) Fire-driven dynamic mosaics in the Great Victoria Desert, Australia. II. A spatial and temporal landscape model. Landsc Ecol 15:407-423

Hoffmann BD (2003) Responses of ant communities to experimental fire regimes on rangelands in the Victoria River District of the Northern Territory. Aust Ecol 28:182-195

Holliday J (1991) Species responses of carabid beetles (Coleoptera, Carabidae) during postfire regeneration of boreal forest. Can Entomol 123:1369-1389

Hurlbert SH (1984) Pseudoreplication and the design of ecological field experiments. Ecol Monogr 54:187-211

Huston MA (1979) A general hypothesis of species diversity. Am Nat 113:81-101

Huston MA (1994) Biological diversity: the coexistence of species on changing landscapes. Cambridge University Press, Cambridge

Hyvarinen E, Kouki J, Martikainen P, Lappalainen H (2005) Short-term effects of controlled burning and green-tree retention on beetle (Coleoptera) assemblages in managed boreal forests. For Ecol Manage 212:315-332

Koch K (1989) Die Käfer Mitteleuropas-Ökologie. Goecke and Evers

Koricheva J, Mulder CPH, Schmid B, Huss-Danell K (2000) Numerical responses of different trophic groups of invertebrates to manipulations of plant diversity in grasslands. Oecologia 125:271-282

Legendre P, Legendre L (1998) Numerical ecology. Elsevier, New York

Li J, Loneragan WA, Duggin JA, Grant CD (2004) Issues affecting the measurement of disturbance response patterns in herbaceous vegetation-a test of the intermediate disturbance hypothesis. Plant Ecol 172:11-26

Ludwig D, Walker BH, Holling CS (1997) Sustainability, Stability, and Resilience. Conservation Ecology [online], 1, 7. URL: http://www.consecol.org/vol1/iss1/art7/

Mantel NA (1967) The detection of disease clustering and a generalized regression approach. Cancer Res 27:209-220

Martikainen P, Siitonen J, Punttila P, Kaila L, Rauh J (2000) Species richness of Coleoptera in mature managed and oldgrowth boreal forests in southern Finland. Biol Conserv 94:199-209

Marxer P (2003) Oberflächenabfluss und Bodenerosion auf Brandflächen des Kastanienwaldgürtels der Südschweiz mit einer Anleitung zur Bewertung der post-fire Erosionsanfälligkeit. Physiogeographica 33:1-217

Mielikainen K, Hynynen J (2003) Silvicultural management in maintaining biodiversity and resistance of forests in Europe-boreal zone: case Finland. J Environ Manag 67:47-54

Moretti M, Barbalat S (2004) The effects of wildfire on woodeating beetles in deciduous forests on the southern slope of the Swiss Alps. For Ecol Manage 187:85-103

Moretti M, Conedera M, Duelli P, Edwards PJ (2002) The effects of wildfire on ground-active spiders (Arthropoda: Araneae) in deciduous forests on the southern slope of the Alps. J Appl Ecol 39:321-336

Moretti M Obrist MK Duelli P (2004) Arthropod biodiversity after forest fires: winners and losers in the winter fire regime of the Southern Alps. Ecography 27:173-186

Mühlenberg M (1993) Freilandökologie. Quelle \& Meyer, Heidelberg 
Ne'eman G, Dafni A, Potts SG (2000) The effect of fire on flower visitation rate and fruit set in four core-species in east Mediterranean scrubland. Plant Ecol 146:97-104

Niwa CG, Peck RW (2002) Influence of prescribed fire on carabid beetle (Carabidae) and spider (Araneae) assemblages in forest litter in southwestern Oregon. Environ Entomol 31:785-796

Nyström M, Folke C (2001) Spatial resilience of coral reefs. Ecosystems 4:406-417

Obrist MK, Duelli P (1996) Trapping efficiency of funnel- and cup-traps for epigeal arthropods. Mitt Schweiz Entomol Ges 69:367-369

Parr CL, Robertson HG, Biggs HC, Chown SL (2004) Response of African savanna ants to long-term fire regimes. J Appl Ecol 41:630-642

Peterson G, Allen CR, Holling CS (1998) Ecological resilience, biodiversity, and scale. Ecosystems 1:6-18

Peterson GD (2002) Contagious disturbance, ecological memory, and the emergence of landscape pattern. Ecosystems 5:329_ 338

Pickett STA (1989) Space-for-time substitution as an alternative to long-term studies. Likens GE (ed) Long-term studies in ecology: approaches and alternatives. Springer, Berlin Heidelberg New York

Potts SG, Vulliamy B, Dafni A, Ne'eman G, O'Toole C, Roberts S, Willmer P (2003) Response of plant-pollinator communities to fire: changes in diversity, abundance and floral reward structure. Oikos 101:103-112

Potts SG, Vulliamy B, Roberts S, Roberts S, O'Toole C, Dafni A, NE'Eman G, Willmer P (2005) Role of nesting resources in organising diverse bee communities in a Mediterranean landscape. Ecol Entomol 30:78-85

Providoli I, Elsenbeer H, Conedera M (2002) Post-fire management and splash erosion in a chestnut coppice in southern Switzerland. For Ecol Manage 162:219-229

Reed DC, Raimondi PT, Carr MH, Goldwasser L (2000) The role of dispersal and disturbance in determining spatial heterogeneity in sedentary organisms. Ecology 81:20112026

Röder G (1990) Biologie der Schwebfliegen Deutschlands (Diptera: Syrphidae). Bauer, Keltern-Weiler

Rowell A, Moore PF (1999) Global review of forest fires. WWF International, Gland

Saint-Germain M, Larrivee M, Drapeau P, Fahrig L, Buddle CM (2005) Short-term response of ground beetles (Coleoptera: Caradibae) to fire and logging in a spruce-dominated boreal landscape. For Ecol Manage 212:118-126

Seifert B (1996) Ameisen: beobachten, bestimmen. Naturbuch, Augsburg
Siemann E, Haarstad J, Tilman D (1997) Short-term and longterm effects of burning on oak savanna arthropods. Am Midl Nat 137:349-361

Similä M, Kouki J, Martikainen P, Uotila A (2002) Conservation of beetles in boreal pine forests: the effects of forest age and naturalness on species assemblages. Biol Conserv 106:19-27

Sippola AL, Siitonen J, Punttila P (2002) Beetle diversity in timberline forests: a comparison between old-growth and regeneration areas in Finnish Lapland. Ann Zool Fenn 39:69-86

Steffan-Dewenter I, Munzenberg U, Burger C, Thies C, Tscharntke T (2002) Scale-dependent effects of landscape context on three pollinator guilds. Ecology 83:1421-1432

Stephens SL, Moghaddas JJ (2005) Fuel treatment effects on snags and coarse woody debris in a Sierra Nevada mixed conifer forest. For Ecol Manage 214:53-64

Tilman D (1982) Resource competition and community structure. J Ecol 35:1-22

Tinner W, Conedera M, Ammann B, Gäggeler HW, Gedye S, Jones R, Säggesser B, (1998) Pollen and charcoal in lake sediments compared with historically documented forest fires in southern Switzerland since AD 1920. Holocene $8(1): 31-42$

Tinner W, Hubschmid P, Wehrli M, Ammann B, Conedera M (1999) Long-term forest ecology and dynamics in southern Switzerland. J Ecol 87:273-289

Tinner W, Conedera M, Ammann B, Lotter AF (2005) Fire ecology north and south of the Alps since the last ice age. Holocene 15(8):1214-1226

Walker B (1995) Conserving biological diversity through ecosystem resilience. Conserv Biol 9:747-752

Walker B, Kinzig A, Langridge J (1999) Plant attribute diversity, resilience, and ecosystem function: the nature and significance of dominant and minor species. Ecosystems 2:95-113

Wermelinger B, Duelli P, Obrist MK (2002) Dynamics of saproxylophagous beetles (Coleoptera) in windthrow areas in alpine spruce forests. For Snow Landsc Res 77:133-148

Westrich P (1989) Die Wildbienen Baden-Württembergs. Spezieller Teil, Ulmer

Wikars L-O (2001) Immediate effects of fire-severity on soil invertebrates in cut and uncut pine forests. For Ecol Manage 141:189-200

Wildi O, Orloci L (1996) Numerical exploration of community patterns. A guide to the use of MULVA-5, 2nd edn. SBP, Amsterdam

Zar JH (1984) Biostatistical analysis. Prentice-Hall, Englewood Cliffs, N.J. 